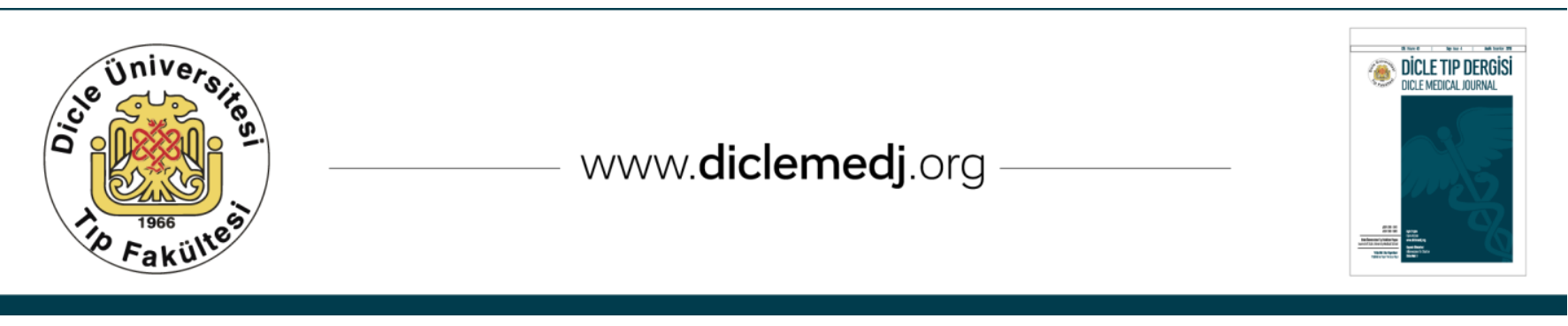

Original Article / Özgün Araștırma

\title{
Investigation of serum oxidative stress levels in patients with nasal polyps
}

\author{
Adnan Ekinci ${ }^{1}$ \\ 1 Hitit University, Faculty of Medicine, Otorhinolaryngology Department, Çorum, Turkey ORCID: 0000-0001-7725-8024
}

Geliş: 25.09.2017 Revizyon: 13.12.2017 Kabul Tarihi: 11.01.2018

\begin{abstract}
Objective: To compare serum total antioxidant status (TAS), total oxidant status (TOS), and paraoxonase (PON1) levels between nasal polyp patients and heal thy subjects.

Method: In the present study, The nasal polyp group includes 26 males an 22 females, a total of 48 patients (mean age $37.11 \pm 12.07$ years), while the control group included 22 males and 24 females, a total of 46 healthy subjects (mean age 36.91 \pm 13.03 ) years. Groups were compared in terms of serum TAS, TOS and PON1 levels.

Results: The mean TAS level was $1.248 \mathrm{mmol} / \mathrm{L}$ in the control group, it was $1.176 \mathrm{mmol} / \mathrm{L}$ in the patient group $(\mathrm{p}=0.044)$. The mean TOS level was $3.443 \mathrm{mmol} / \mathrm{L}$ in the control group, and it was $6.720 \mathrm{mmol} / \mathrm{L}$ in the patient group $(\mathrm{p}=006)$. Nasal polyp and control groups did not show any significant difference for PON1 (301.15 U/L vs. 295.75 $\mathrm{U} / \mathrm{L}, \mathrm{p}>0.05)$.

Conclusion: Serum TOS levels were significantly higher, and TAS levels were significantly lower in patients with nasal polyposis compared it the control group. There was no significant difference between the patients with nasal polypand the control group in terms of the PON1 values.
\end{abstract}

Keywords: Nasal Polyp, Total Oxidant Status, Total Antioxidant Status, Paraoxonase.

DOI: $10.5798 /$ dicletip.407237

Yazışma Adresi / Correspondence: Adnan Ekinci, Üçtutlar Mh, Ahçllar 16,Sokak, Ada Aparmant B Blok no:15 19000, Çorum, Turkey e-mail: $\underline{\text { draekinci@hotmail.com }}$ 


\section{Nazal Polip'li Hastalarda Serum Oksidatif Stres Düzeylerinin Araștırılması}

Özet

Amaç: Nazal polip hastaları ile sağlıklı bireyler arasında serum total antioksidan status (TAS), total oksidan status (TOS) ve paraoksonaz (PON1) düzeylerini karşllaştırmak.

Yöntemler: Çalışmamızda nazal polip grubunda 26 erkek, 22 kadın, toplam 48 hasta (ortalama yaş $37.11 \pm 12.07$ yıl), kontrol grubunda 22 erkek ve 24 kadın olmak üzere toplam 46 sağlıklı birey (ortalama yaş $36.91 \pm 13.03$ ) dahil edildi. Gruplar serum TAS, TOS ve PON1 düzeyleri açısından karşılaştırıldı.

Bulgular: Ortalama TAS düzeyi kontrol grubunda $1.248 \mathrm{mmol} / \mathrm{L}$, hasta grubunda $1.176 \mathrm{mmol} / \mathrm{L}$ idi $(\mathrm{p}=0.044)$. Kontrol grubunda ortalama TOS düzeyi $3.443 \mathrm{mmol} / \mathrm{L}$, hasta grubunda $6.720 \mathrm{mmol} / \mathrm{L}$ bulundu $(\mathrm{p}=006)$. nazal polip ve kontrol grupları PON1 düzeyleri bakımından anlamlı bir fark görülmedi. (301.15 U / L' vs295.75 U / L, p> 0.05).

Sonuç: Serum TOS düzeyleri, kontrol grubuna göre nazal polipozisli hastalarda anlamlı olarak daha yüksek ve TAS düzeyi anlamlı olarak düşük olarak tespit edildi. Nazal polip ve kontrol grubu arasında PON1 değerleri açısından anlamlı fark tespit edilemedi.

Anahtar kelimeler: Nazal Polip, Total Oksidan Durumu, Total Antioksidan Durum, Paraoksonaz

\section{INTRODUCTION}

Nasal polyp is a benign disease characterized by the growth of the nasal mucosa to the nasal cavity due to various causes and they are the most common causes of nasal masses ${ }^{1}$. Allergic, infectious, mechanical, immunological and biochemical factors have been considered to play a role in the etiopathogenesis ${ }^{2}$.Nasal polyp tissue contains high amounts of eosinophils, neutrophils, macrophages, lymphocytes and myofibroblasts, which lead to overproduction of reactive oxygen species (ROS). Epithelial cell damage occurs due to high amount of those inflammatory cells, particularly eosinophils, and the products of those cells, including ROS 3 5 .

There is a balance between oxidant and antioxidant molecules in the body. In case this balance is changed in favor of oxidants, oxidative stress, and hence free radical damage occurs $^{6}$. Free oxygen plays a role in the pathogenesis of many diseases such as radicals, diabetes, atherosclerosis, Bechet's disease, tumors, rheumatological and dermatological diseases ${ }^{4}$.
In recent years, a number of studies focused on the oxidant/antioxidant molecules due to their roles in diseases. The concentration of each oxidant molecule in the plasma can be determined alone, but the oxidant molecules can interact with each other. Because of this interaction of antioxidant molecules, a new method, total oxidant status (TOS) measurement, was developed by Erel and its usage became widespread recently.7,8.

Similarly, measurement of the total antioxidant status (TAS) gives more valuable information than the measurement of the levels of antioxidants separately. Therefore, measurement of TAS, which gives the total antioxidant status, became more common than the measurement of individual antioxidants ${ }^{7}$. Paraoxonase (PON1), which works as a strong antioxidant, is a high density lipoprotein (HDL) associated hydroxylase that can hydroxylase paraxone which is a potent inhibitor of cholinesterases 9,10 .

In this study, we aimed to determine TAS, TOS and PON1 levels in serum in order to determine oxidative stress levels in nasal polyposis patients. We want to contribute to the 
literature because of the limited number of studies on this issue.

\section{METHODS}

The present study was carried out between January 15 and July 01, 2016 in Hitit University, otolaryngology department. Gaziosmanpaşa University Clinical Research Ethics Committee approved to work. (Decree No. 15, KAEK190).A total of 48 patients diagnosed with nasal polyps, and 46 healthy subjects were included in the study. There were 26 were males and 22 were females with a mean age of 38.1 years in the nasal polyp group. The control group consisted of 46 subjects, 22 males and 24 females, with a mean age of 36.9 years. All participants provided their written informed consents for participating in the study. The diagnosis of the patients was made by direct and endoscopic examinations. The nasal polyp patients with atherosclerosis, malignant tumor, hypertension, chronic inflammatory diseases, diabetes mellitus and nasal disorders such as antrochoanal polyp, inverted papilloma were excluded. The subjects in the control group did not have any systemic diseases, bronchial asthma or nasal disorders including chronic sinusitis, nasal polyps and allergy. None of the patients or controls were smokers or consumed alcohol.

Serum samples were collected from patients with nasal polyps and control group before any medical or surgical treatment was applied. Ten milliliters of venous blood sample was drawn into vacuumed test tubes between 8:00 and 10:00 AM to measure TAS, TOS and PON1. After waiting for 30-45 minutes, blood was centrifuged at 4000 RPM for 10 minutes, serum was separated, and stored in an Eppendorf tube at suitable cold.

Biochemical Measurements: TAS and TOS measurements developed by Erel were used for measurements. ${ }^{7,9}$ Determination of TOS was performed by a full automatic kit developed by Erel (RelAssay Diagnostics kit, Mega Tıp, Gaziantep, Turkey), which was measured colorimetrically by an autoanalyser (VitalScientific, Selectra/Flexor E, Dieren, Netherlands). The measurement results were expressed as $\mu \mathrm{mol} \mathrm{H} 2 \mathrm{O} 2$ equivalent/L7.TAS was measured with fully automated RelAssay® kit (Gaziantep, Turkey) using Abbott Architect ${ }^{\circledR} \quad$ c16000 autoanalyzer. The measurement results were expressed as mmol/L (micromolartrolox/L) ${ }^{7,8}$. PON1 levels were determined with the RelAssay ${ }^{\circledR}$ kit (Gaziantep, Turkey) with Abbott Architect $\AA$ c16000 autoanalyzer. The measurement results were expressed as $\mathrm{U} / \mathrm{mol}^{7}$.

Statistical analysis: SPSS (Version 22.0, SPSS Inc. Chicago, USA) package program was used for statistical analysis. The Shapiro-Wilk test was used to analyze the distribution normals. The mean \pm standard deviation, median (minmax), and categorical variables were used in the continuous variables presentation. Independent sample t-test was used to test continuous variables. If the variables are normally distributed, the two independent variables are compared. Non- normally distributed samples were compared with the Mann-Whitney U test. For significance level, p $<0.05$ was determined.

\section{RESULTS}

The nasal polyp group includes 26 males an 22 females, a total of 48 patients (mean age $37.11 \pm 12.07$ years), while the control group included 22 males and 24 females, a total of 46 healthy subjects (mean age $36.91 \pm 13.03$ ) years. The mean age and sex did not significantly differ between the two groups ( $p>0.05$ for both). A statistically significant difference was found between the mean TAS values in the control group and the nasal polyp group. The mean serum TAS level was $1.25 \pm 0.16 \mathrm{mmol} / \mathrm{L}$ in the control group and $1.18 \pm 0.18 \mathrm{mmol} / \mathrm{L}$ in the nasal polyp group. TAS values were significantly lower in the patient group ( $\mathrm{p}=$ 0.044) (Table 1). When the mean TOS values were compared between the groups, it was also found that the TOS values were statistically 
different between the groups. The mean TOS level was $3.44 \pm 8.34 \mathrm{mmol} / \mathrm{L}$ in the control group and $6.72 \pm 11.21 \mathrm{mmol} / \mathrm{L}$ in the nasal polyp group. TOS values were significantly higher in the patient group $(\mathrm{p}=0.006)$ (Table 2). The mean PON1 levels were $301.15 \pm 177.97$
$\mathrm{U} / \mathrm{L}$ and $295.75 \pm 187.49 \mathrm{U} / \mathrm{L}$ in the control and nasal polyp groups, respectively $(\mathrm{p}=0.922)$ (Table 3). The mean changes of TAS, TOS and PON1 values are shown in boxplot graph form in Figure 1 ( $a, b$ and c, respectively).

Table 1: Comparison of nasal polyp and control groups in terms of total antioxidant status.

\begin{tabular}{lcccc}
\hline Group & N & Mean \pm SD & Median $($ min-max $)$ & $p$ value \\
\hline Polyp & 48 & $1.18 \pm 0.18$ & $1.18(0.84-1.52)$ & 0.044* \\
Control & 46 & $1.25 \pm 0.16$ & $1.24(0.95-1.72)$ & \\
\hline Total & 94 & $1.21 \pm 0.17$ & $1.22(0.84-1.72)$ \\
\hline
\end{tabular}

Table 2: Comparison of nasal polyp and control groups for total oxidant status.

\begin{tabular}{lcccc}
\hline Group & N & Mean \pm SD & Median $($ min-max $)$ & $p$ value \\
\hline Polyp & 48 & $6.72 \pm 11.21$ & $1.81(0.02-36.63)$ & 0.006* \\
Control & 46 & $3.44 \pm 8.34$ & $0.93(0.04-35.42)$ & \\
\hline Total & 94 & $5.12 \pm 9.99$ & $1.64(0.02-36.63)$ \\
\hline
\end{tabular}

Table 3: Comparison of nasal polyp and control groups for paraxonase levels.

\begin{tabular}{lllll}
\hline Group & N & Mean \pm SD & Median (min-max) & $p$ value \\
\hline Polyp & 48 & $295.75 \pm 187.49$ & $214.00(92-956)$ & 0.922 \\
Control & 46 & $301.15 \pm 177.97$ & $240.50(81-688)$ & \\
\hline Total & 94 & $298.39 \pm 181.93$ & $220.50(81-956)$ \\
\hline \multicolumn{5}{c}{ SD: Standard Deviation, Min: Minimum, Max: Maximum }
\end{tabular}

\section{DISCUSSION}

In this study, we found a statistically significant difference between TAS and TOS values between patient and control groups. The serum TOS levels were signifycantly higher, and TAS levels were signifycantly lower in patients with nasal polyposis compared to the control group. There was no significant difference between the patients with nasal polyp and the control group in terms of the PON1 levels.

Reviewing the literature, we recognized that the PON 1 enzyme together with the TAS and
TOS, which have become popular in recent years, have not been satisfactorily investigated in nasal polyp patients although various oxidative parameters have been investigated before. For this reason, we investigated the TAS, TOS and PON1 altogether in nasal polyp patients. For this reason, TAS, TOS and PON1 levels were investigated in patients with nasal polyps. When we examined the literature, we found that TAS, TOS and PON1 enzymes were commonly studied in similar studies. That's why we added PON1. The normal appearance 
of PON1 enzyme levels despite a low TAS value appears to be a meaningful result. It has been determined that this reduction in TAS in our study was due to the reduction of other antioxidants except PON1. In the body, oxidants and antioxidants are normally found in equilibrium. Oxidative stress occurs if this balance is changed in favor of the oxidants 6 . The TAS values, which reflects the total antioxidant value, has become more widespread than the measurement of antioxidants individually ${ }^{7}$.TOS measurement has been developed instead of individual measurements of oxidant molecules since oxidant molecules have the potential to interact with each other ${ }^{7,8}$.The relationship between oxidative stress and some diseases has been investigated in the literature. For example, nasal polyps, adenotonsillar hypertrophy, obstructive sleep apnea and Bechet's Disease ${ }^{11-}$ 14. The number of studies demonstrating the role of oxidative stress in the pathogenesis of nasal polyp has increased in recent years. A direct relationship between nasal polyps and oxidative stress has not been clarified so far. But we believe that oxidative stress may increase due to low oxygen saturations in patients who have respiratory distress due to nasal polyps

Haoet al ${ }^{15}$ investigated serum oxidative stress levels in nasal polyposis patients in their study.
ARE, PON1 and TAS levels in patients with nasal polyps were lower than in the control group. TOS and OSI levels were also significantly higher in the nasal polyp group. For this reason, it has been reported that oxidative stress may play an effective role in the etiopathogenesis of nasal polyps. In the present study, we found statistically significant difference between nasal polyp and control groups in terms of the TAS and TOS levels. Serum TOS levels were significantly higher, and TAS levels were significantly lower in patients with nasal polyps compared to the control group. However, We found no significant difference between the groups in terms of PON1 levels.

Hartnellet al. ${ }^{16}$ reported that antioxidant substances decreased, but a peroxidation product, malondialdehyde (MDA) increased in the tissues and blood of nasal polyp patients. Similarly, Dağlı et al. ${ }^{17}$ found that the serum and tissue antioxidant levels decreased, and MDA increased in nasal polyp patients, and interpreted this as a strong effect of oxidative stress in the pathogenesis of nasal polyps. Karlıdağ et al. ${ }^{3}$ also found increased tissue MDA and NO, and decreased antioxidant levels in nasal polyp patients, indicating a free oxygen radical damage.

Figure 1.Boxplots of mean changes in TAS (a), TOS (b) and PON1 (c) according to groups
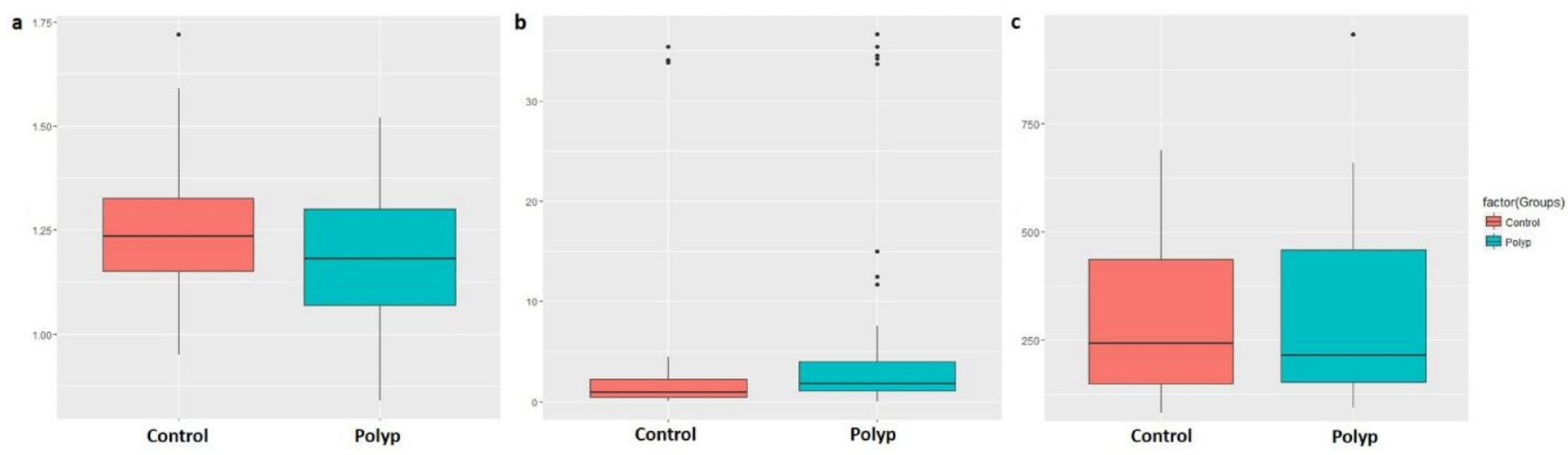
Taysı et al. ${ }^{18}$ found lower GSH-Px activity but significantly higher catalase and xanthine oxidase activities and MDA levels in the nasal polyp tissues as compared to the concha bullosa tissues of the control group. Bozkuş et al. ${ }^{11}$ reported that oxidative stress levels were increased both in serum and polyp tissue in patients with nasal polyps in their study of nasal polyposis. Similar to aforementioned studies, Cheng et al. ${ }^{19}$ found high SOD1 and SOD3 levels in nasal polyp tissues, and stated that their findings supported the hypothesis of oxidative stress in nasal polyps.

In the present study, serum TOS levels were significantly higher in the nasal polyp group and TAS levels were significantly lower in the nasal polyp group. Increased TOS levels and decreased TAS levels suggest that oxidative stress may be effective in the development of nasal polyps. There are some limitations of this study. The relation between nasal polyp grade, patient complaint scores and oxidative parameters has not been investigated. In addition, we suppose that investigation of the serum and tissue TAS and TOS values before and after surgery in nasal polyp patients would be beneficial.

\section{CONCLUSION}

As a result we have found that oxidative stress levels increase in nasal polyposis patients. Larger and more comprehensive studies are needed on this subject.

Declaration of Conflicting Interests: The authors declare that they have no conflict of interest.

Financial Disclosure: No financial support was received.

\section{REFERENCES}

1. Koc C: Nazal Polip, otolaryngology, head and neck surgery. (Ed. Koc C), Ankara, Güneş bookstore 2004; 609-624.

2. Bateman ND, Fahy C, Woolford TJ. Nasal polyps: still more questions than answers. J Laryngol Otol. 2003; 117: 1-9.

3. Karlıdag T, İlhan N, Kaygusuz İ, Keles E, Yalçin S, Yildiz M. Roles of free radicals, nitricoxide and scavenging enzymes in nasal polyp development. Ann Otol Rhinol Laryngol. 2005; 114:122-6.

4. Uslu C, Taysı S, Bakan N. Lipid peroxidation and some antioxidant enzyme activities in experimental maxillary sinusitis. Ann Clin Lab Sci. 2003;33:18-22.

5. Norlander T, Westrin KM, Fukami M, Stierna P, Carlsöö B. Experimentally induced polyps in the sinus mucosa: a structural analysis of the initial stage. Laryngoscope. 1996; 106:196-203.

6. Si-es H. Oxidants and antioxidants. Exp Physiol. 1997; 82: 291-5.

7. Erel O. A new automated colorimetric method for measuring total oxidant status. Clin Biochem. 2005; 38: 1103-11.

8. Erel O. A novel automated method to measure total antioxidant response against potent free radical reactions. Clin Biochem. 2004; 37:112-19.

9. Ozdin M. Gursu M.F. Investigation of paraoxonase 1 and arylesterase activities and phenotypes in patients with coronary heart disease and various risk factors. Expertise Thesis, Firat University, Faculty of Medicine, Biochemistry Department, Elazıg, Turkey. 2003;17-19.

10. Durrington PN, Mackness B, Mackness MI. Paraoxonase and Atherosclerosis. Arterioscler Thromb Vasc Biol. 2001;21:473-80.

11. Bozkus F, San, T. Ulas T, et al. Evaluation of total oxidative stress parameters in patients with nasal polyps. Acta Otorhinolaryngol Ital. 2013; 33:248-53.

12. Dogruer ZN, Unal M, Eskandari G, et al. Malondialdehyde and antioxidant enzymes in children with obstructive adenotonsillar hypertrophy. Clin Biochem. 2004; 37: 718-21.

13. Del Ben M, Fabiani M, Loffredo L, et al. Oxidative stress mediated arterial dysfunction in patients with obstructive sleep apnoea and the effect of continuous positive airway pressure treatment. BMC Pulm Med. 2012; 23:12-36. 
14. Sandikci R, Turkmen S, Guvenen G, et al. Lipid peroxidation and antioxidant defence system in patients with active or inactive Behcet's disease. Acta Derm Venereol. 2003; 83:342-6.

15. Hao W, Zhu Y, Meng L, Ni C, Yang J, Zhou H. Serum paraoxonase, arylesterase activity, and oxidative status in patients with nasal polyp. Eur Arch Otorhinolaryngol. 2013; 270:1861-5.

16. Hartnell A, Heinemann A, Dolores $M$, et al. Identification of selective basophil chemo attractants in human nasal polyps as insulin-like growth factor-1 and insulin-like growth factor-2. J Immunol. 2004; 173:10,6448-57.
17. Daglı M, Eryllmaz A, Besler T, Akmansu H, Acar A, Korkmaz H. Role of free radicals and antioxidants in nasal polyps. Laryngoscope. 2004;114:1200-3.

18. Taysı S, Uslu C, Yılmaz A, Aktan A, Aktan B, Altas E. Lipid peroxidation and some antioxidant enzymes in nasal polyp tissue. Cell Biochem Funct. 2006; 24:461-5.

19. Cheng YK, Hwang GY, Lin CD, Tsai MH, Tsai SW, Chang WC. Altered expression profile of superoxide dismutase isoforms in nasal polyps from nonallergic patients. Laryngoscope. 2006;116:417-22. 